\title{
News Text on Kompas.com Media of Covid-19 and the Underlying Conspiracy Theory: A Teun Van Dijk's Critical Discourse Analysis
}

\author{
Veronika Unun Pratiwi ${ }^{1}$, Nofrahadi ${ }^{2}$, Apri Pendri $^{3}$, Dina Komalasari ${ }^{4}$, Sumarlam $^{5}$ \\ ${ }^{1}$ Universitas Veteran Bangun Nusantara Sukoharjo, Indonesia \\ 1,2,3,4,5 Universitas Sebelas Maret, Indonesia \\ ${ }^{4}$ Universitas Muhammadiyah Buton, Indonesia \\ pratiwiunun@yahoo.co.id,nofrahadi11@student.uns.ac.id,apripendri15@student.uns.ac.id, \\ dinakomalasari@student.uns.ac.id,sumarlam@staff.uns.ac.id
}

\begin{abstract}
This article critically examines the news of the coronavirus (COVID-19) pandemic in the press. This article tries to examine how the COVID-19 news is used for political and ideological purposes. To achieve this goal, an analysis was carried out on the Kompas.com Online Media newspaper on 11 June 2020 and 05 September 2020. The Van Dijk news scheme framework is used to analyze reports selected from selected topics of Covid 19. Van Dijk's news scheme is very important to analyze every news (report) whether the news is taken from news channels or newspapers and whether broadcast or printed. Based on data analysis, the article found that COVID-19 news had been politicized and used for ideological purposes. The article recommends that a pandemic should not be politicized by either the media or any party, but we must work together so that the government and media personnel are able to work effectively and deal with this long-running pandemic.
\end{abstract}

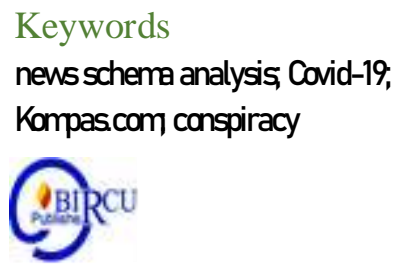

Keywords

news schema analysis, Covid-19, Kompascom conspiracy

\section{Introduction}

The print media have a profound influence on public opinion and are the main channel of communication between decision makers and the public. The power of media comes from its influence on the crystallization of our thoughts. The mind functions like a machine that moves and controls our actions and behavior. The media have the ability to work day and night for the purpose of shaping perceptions, manipulating, and changing beliefs, regardless of whether they are positive or negative changes, acceptable or rejected, beneficial or detrimental, loved or hated.

Hofstetter and Buss (1978) describe that the polemic about the word 'bias' in ordinary language is basically slanted. In other words, bias presents something like news in a way that sided with certain groups or opinions (bias interpreted or presented someone or something ideologically for special interests). Bias also reports problems, problems, actors, politicians, and certain other political events not as they are. The bias is not free from lies, distortion and spread of certain facts, disagreements over basic values, beliefs or customs.

Mullainathan and Shleifer (2002) emphasize the fact that information can be manipulated in different ways: ignoring or removing information that contradicts or does not match the message from the news, looking for sources of information that can strengthen or reinforce the story, ignoring, demeaning, and destroying information sources that are does not conform to the message, or uses distracting and deceptive language and images that support the news. It cannot be denied that media bias, news bias, and information 
manipulation cannot be achieved without this language. Language serves as a powerful tool on which media owners depend in conveying their ideology and manipulation (Thomas, et al., 2004). Kolsto (2009) argues that the media are controlled politically. This political control has a profound impact on his response to any kind of crisis or event.

The propaganda behind the Covid-19 pandemic, while propaganda itself is not a new problem that is always bad and negative that we need to get rid of as humans. History proves that pandemics were politicized and used for ideological and political purposes. Dangerous diseases such as 1918 H1N1 flu, AIDS, Ebola were politicized (Adida, et al., 2007, Cotter, 2020; Qiu, 2017, Scott, 2014). In fact, history does not repeat itself, but teaches us lessons and inspires us to respond and act differently to current crises in order to get positive and good results from our previously negative ones. Unfortunately, we haven't learned from previous crises and disasters; instead we stubbornly politicize and invest the current deadly COVID-19 pandemic for political and ideological purposes. Scott (2014) emphasizes that disease and responses to disease are always politicized and always have political consequences. The Ebola virus was politicized just like the previous viruses. COVID-19 is a virus like previous viruses such as the plague, $1918 \mathrm{flu}$, Asian flu, Cholera, AIDS, SARS, Ebola, Zika, SARS, and MERS. It's a virus and it's a law of nature. Instead of working together to defeat this deadly disease, the government, especially the one in power, is busy exchanging accusations. Zhao Lijian, a spokesman for the Chinese Ministry of Foreign Affairs accused the United States of spreading the pandemic in Wuhan, the epicenter of the COVID-19 outbreak (Huang, 2020) [10, 16]. President Trump responded by labeling the virus the "Chinese virus". Then, Secretary of State Mike Pompeo called the virus the "Wuhan virus" (Marcus, 2020). The exchange of accusations between China and the US continues. The US has even asked to open an investigation linking the virus to the Wuhan laboratory.

Page (2020) emphasized that becoming a pandemic as a political issue is clearly dangerous for national health. Stigmatizing a nation or state for its responsibility in a disaster does not produce a vaccine or cure for the virus, but rather complicates it. When racism, stereotypes, hate speech and propaganda are combined with intense fear and terror from an illness, more problems are bound to arise. Social media and means of communication can make situations more difficult than expected. Distorted and misinformation, manipulation, ideology, conspiracy theories, undocumented claims and inaccurate conclusions can spread faster than the virus itself. Politicizing the pandemic and broadcasting fear and hate speech will lead to discrimination and stigmatization of "the other person" in a wrong, unthinkable, and bad way (Cotter, 2020). Politicizing disease can shape people's attitudes about immigration, the case in the US. The Chinese Exclusion Act was the first immigration law passed in 1882. Because of the threat of disease and after decades of stereotyping Chinese immigrants and believing that Chinese people carry diseases such as cholera and smallpox, the law prohibits Chinese people from immigrating to the United States. The Scott Act of 1888 was introduced to severely restrict and prevent Chinese people from immigrating to the US. Such laws and views are detrimental to the entire community and at the same time do not stop the spread of disease. The flu pandemic that was first identified in China in the late 1950s is known as the "Asian Flu". Another flu pandemic that emerged in Hong Kong in the late 1960s was called the "Hong Kong Flu". The H1N1 flu 2009-2010 which the US first classified was known as "swine flu". The media coverage of the flu emphasizes that the flu may have originated in Mexico, which again aroused fears from migrants (Little, 2020).

Politicizing the pandemic encourages ethnic and racial discrimination among peoples of different races and countries. This raises political, social, and even health problems. It also encourages people to engage in hate speech, fake news and aggression. Therefore, we must avoid disinformation, distortion, racial rhetoric, derogatory expression, ideology, 
manipulation and propaganda. In other words, we must work together to control disease and overcome it. In the end, the virus knows no boundaries and does not differentiate between colors, religions and beliefs.

\section{Review of Literatures}

\subsection{Van Dijk's News Schema (1985; 1991)}

Bukhari and Xiaoyang (2013) explain that Van Dijk proposes an analysis of 'structure at various levels of description' starting from the phonological, morphological, grammatical, and semantic levels to higher levels such as coherence, themes and topics related to different and overall news schematic and rhetorical dimensions of text. Yarlott et al., (2018) stated that: Discourse structure is a key aspect of all forms of text, providing valuable information about the content of a certain range of text. This is most evident in academic, legal, and technical texts, which are often clearly drawn into sections containing, for example, an introduction, background, or explanatory material, among others these types of text are designed to make it easier to find specific information in inside quickly. News articles have the same helpful, though implied, design: they often provide brief up-front summaries of key events, relevant background information, comments from experts and journalists, and detailed descriptions of key events. Events are often not presented in chronological order, but rather arranged according to importance (van Dijk, 1988). Drid (2019) describes Van Dijk's framework for news discourse analysis relying on two levels of systematic structure: global structures and local structures. The global structure consists of two discourse structures, namely macrostructure and superstructure. Local structure including micro. Zhang et al. (2014) stated that: Van Dijk's study of news discourse has its own characteristics. He believes that discourse is a kind of social control force, which represents the will of authority, and reflects specific power structures. The masters of and dissemination of discourse are news journalists, writers, artists and scholars. These people are called the "symbolic elite". People in power have the right to control all kinds of discourse, while ordinary people can only control everyday discourse. Van Dijk's study aims to see how powerful people carry out, express, describe, or hide their ambitions through context and discourse. In particular, he paid great attention to the role of ideology. He has conducted a number of media discourse surveys, such as news reports, TV programs and advertisements. Its purpose is to describe how western authorities control the form and content of discourse, and further control societal beliefs and ideologies (200-201). Van Dijk (1985; 1991) examines news as discourse. All of these studies provide the writer with a useful framework (news schema) for analyzing any news or report from any channel or newspaper. The three discourse structures, namely, macrostructure, superstructure, and microstructure are very important for the analysis of selected news.

\subsection{Macrostructure}

Thematic learning is defined as a learning activity by integrating the material of several subjects into one discussion theme (Rafida and Jamilah, 2020). Discourse macrostructure is thematic in nature. In other words, macrostructure is the subject or topic discussed or described and forms the basis of the whole story. Thematic analysis deals with the main theme or topic of a particular text. Topics and themes describe and express social and psychological statements that are different from any text or news (Pratiwi and Refnaldi, 2018). In news or news, the macro structure is expressed in the headline and main paragraph. 


\subsection{Superstructure}

The superstructure is a schema. It shows the main parts of a story and how they are organized. The news superstructure consists of three main parts, namely introduction, substance, and conclusion. News consists of introduction (represented by the first paragraph of the story), substance (content) (essence or main story), and conclusion (closing) (the last part, the result or the end result of a story) news stories) (Aini \& Widodo, 2018; van Dijk, 1991).

\subsection{Microstructure}

It focuses on lexical items (words) and selected sentences that are used to form a story. According to Van Dijk (1991), news cannot be separated from the following different aspects of meaning: presuppositions, implications, conclusions, concealment, euphemisms, rejection of forms of denial, blame the victim, negativisation, and in general the combined strategy of positive self-presentation and presentation. - another negative. Many of these semantic features involve various forms of implication or indirectness (177). All aspects of meaning in ideology are hidden where these aspects cannot be found without the help of a discourse microstructure (Van Dijk, 1991). According to Priadi et al (2018) News texts that are present as a result of the construction of journalists are displayed using language so that they can be read and seen by the public.

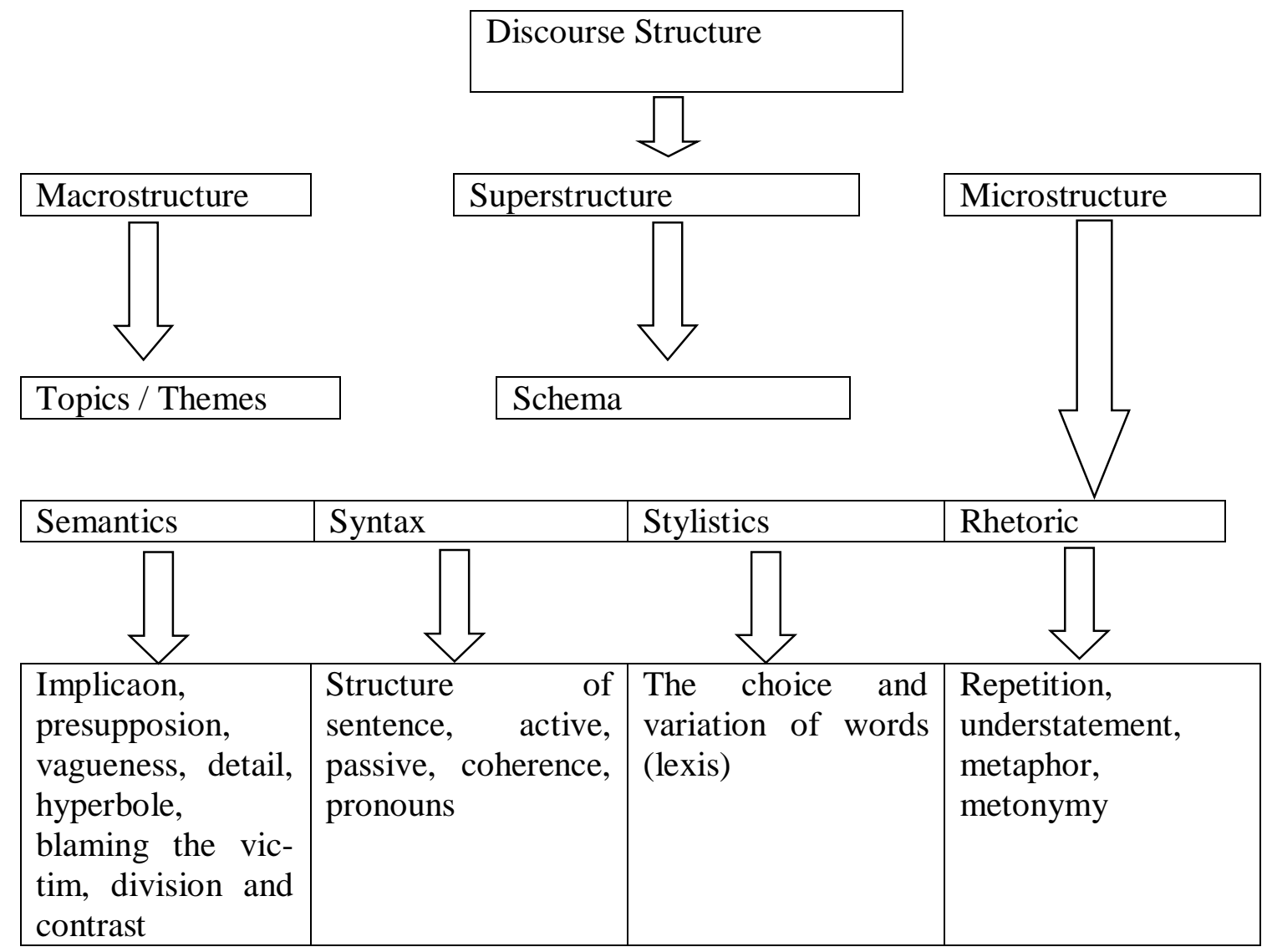

Figure 1. Adapted from Van Dijk, 1991, Racism and the Press 


\section{Reseach Methods}

This study was designed with a descriptive-qualitative research model using Teun van Dijk's critical discourse analysis method. The data source used in this study is divided into two parts, namely primary data and secondary data. The primary data source is in the form of news about two news articles published in online daily news with different time spans "Why is Bill Gates Often the Target of Corona Virus Conspiracy Theory Accusations" (Kompas.com Online Media, 11 June 2020) \& "6 Months of the Covid-19 Pandemic: Hoaxes and Conspiracy Theories that Exacerbate Handling (05 September 2020) "while for secondary data the authors try to find research journals that are correlated with this study. The object of this study is the text of news about Covid-19 and the conspiracy theory behind it. The data collection technique is to understand and analyze the data obtained from Kompas.com online daily news. The texts analyzed were: the primary data source in the form of direct news report analysis with reading and understanding processes from Kompas.com. Documentation methods, observation methods and note-taking techniques were used in this study. The data analysis technique consists of several level structures, each of which supports each other. There are levels in text analysis: macro structure, supersture, and microstructure. Then look for and classify sentences and their meanings based on the three elements above.

\section{Discussion}

\begin{tabular}{|c|c|c|}
\hline $\begin{array}{l}\text { Published date } \\
\text { News headlines } \\
\text { Length of the news } \\
\text { News main features }\end{array}$ & & $\begin{array}{l}\text { https://www.kompas.com/ on June } 11,2020 \\
\text { "Mengapa Bill Gates Sering Jadi Sasaran Tudingan Teori } \\
\text { Konspirasi Virus Corona" } \\
605 \text { words } \\
\text { The Covid } 19 \text { conspiracy, which suspects leaders of the global } \\
\text { elite class to be involved in it, claims Bill Gates is the } \\
\text { mastermind behind the case of the spread of the Covid-19 } \\
\text { virus with the aim of reducing the world's population. The } \\
\text { development of a Covid-19 virus vaccine funded by Bill Gates } \\
\text { has been interpreted by the public as a conspiracy. }\end{array}$ \\
\hline $\begin{array}{l}\text { Published date } \\
\text { News headlines } \\
\text { Length of the news } \\
\text { News main features }\end{array}$ & & $\begin{array}{l}\text { https://nasional.kompas.com/ on September 5, } 2020 \\
\text { "6 Bulan Pandemi Covid-19: Hoaks dan Teori Konspirasi } \\
\text { yang Memperparah Penanganan" } \\
909 \text { words } \\
\text { Focused on the report of the chairman of Mafindo, Septiaji on } \\
\text { hoax information and the alleged conspiracy behind the } \\
\text { Covid-19 pandemic which reduced the level of public } \\
\text { compliance with health protocols and intimidation of medical } \\
\text { personnel profiting from this outbreak, exacerbating the } \\
\text { handling of the Covid-19 outbreak. }\end{array}$ \\
\hline
\end{tabular}

\subsection{First News}

In terms of macro structure, the first news of Kompas.com had the following headlines "Mengapa Bill Gates Sering Jadi Sasaran Tudingan Teori Konspirasi Virus Corona" headlines are very important in presenting the main theme or topic of a story. Through the help of headline, one can understand what the story is talking about. Starting 
with the first title, question mark (rhetorical sentence) mengapa...... Rhetorical structure relates to how the news writer emphasizes certain meanings in the news. This structure will see how news writers use rhetorical word choices that start with "mengapa" which aims to emphasize the issue but return the conclusion of the truth of the news to the audience. The initiative of Bill Gates and a number of other elite figures, the wealthy elite with his company, as part of a high-level conspiracy. In this news, one of the theories that connects Bill Gates as the mastermind behind the Covid-19 pandemic is motivated by his speech in 2015 which predicts the existence of a deadly virus that kills more than war. This assumption is reinforced by the actions of Bill Gates through the Bill and Melinda Gates Foundation, which recently funded the Corona vaccine where this series of actions led to public accusations that the Covid 19 pandemic was propaganda driven by world elites like Bill Gates for a specific purpose, namely reducing the world's population.

Microstructure deals with all semantic, syntactic, lexical, and rhetorical aspects of discourse, and in this case, news. In terms of semantics, the details are more contextual, a number of supporting propositions or ideas that indicate Bill Gates was involved in the Covid 19 pandemic. In the news editorial, the author states his personal opinion "pasalnya, hal itu telah menjadi amunisi teori konspirasi sejak lama" which confirms Professor Joseph Uscinski's accusations against the global elite. In the opinion of researchers, journalists or news writers actually want to lead readers' opinions on the possibility of a large global elite propaganda in the Covid-19 case. The author also adds other evidence that has the potential to lead readers to justify the existence of Covid-19 propaganda "Pemeriksa fakta di First Draft, Rory Smith mengatakan, sering kali ada kebenaran yang kemudian dikaitkan dengan berkembangnya teori itu, meski dengan konteks berbeda" after explaining information that supports the truth of Covid-19 propaganda. In addition, it presents an illustration of a waiter wearing while serving customers who eat and drink on the cafe terrace of the Le Bar du Marche restaurant in Paris, France, according to researchers that so far, even though at that time in June 2020 the pandemic was still in a dangerous phase. Countries in Europe at that time were still implementing lockdowns, but in their reporting, journalists used the momentum in this photo to lead the public opinion that in the West, Western people themselves might believe in the elite propaganda behind the pandemic.

"Seorang pelayan mengenakan masker
wajah saat melayani pelanggan yang
makan dan minum diteras cafe restoran
Le Bar du Marche, di Paris, Perancis,
Juni 2020. Restoran dan cafe mulai
buka setelah Perancis melonggarkan
kebijakan lockdown di negaranya".
(AFP/BERTRAND GUAY).
Free Translation: A waiter wears a face
mask while serving customers who eat
and drink on the terrace of the cafe
restaurant Le Bar du Marche, in Paris,
France, June 2, 2020. Restaurants and
cafes are starting to open after France
relaxed its lockdown policy in the
country.


News related to global elite propaganda by Kompas.com journalists informing their readers about the suspicion of involvement of Bill Gates and his company in creating the disaster and the Covid-19 pandemic does not end with objective suggestions and reporting of the existence of this propaganda if it is interpreted in a narrow view instead it had fatal consequences and worsened the situation during the Covid-19 pandemic.

\subsection{Second News}

In the second headline, entitled "6 Bulan Pandemi Covid-19: Hoaks dan Teori Konspirasi yang Memperparah Penanganan" The news behind the headline implies a proposition / argument where hoax cases and conspiracy theories linking the evil intentions of the global elite are news that need to be ignored because they have the potential to confuse the situation and disrupt the struggle of medics in helping to handle the Covid-19 case. Of course, there is a difference in this more recent news (5 September 2020) than the previous news on the first data. Microstructure uses semantic, syntactic, lexical, and rhetorical reflection to uncover hidden ideologies in the news. In terms of semantics, the content of national news.kompas.com provides more contextual details that suggest a shift in tendency towards the previous Covid-19 issue. After previously this newspaper ideologically led to an opinion about the existence of a conspiracy, here it appears that Kompas is trying to sympathize with the impact of the ineffective handling of Covid-19 due to individuals who suspect that there is a conspiracy and propaganda behind the pandemic issue. In the editorial message "mengingat derasnya arus informasi di tengah era digital seperti saat ini. Bila tak hati-hati, seseorang dapat menjadi korban hoaks", it seems that the author encourages the public to be able to see objectively based on existing facts and not easily believe in any efforts that ignore health protocols.

In terms of the use of lexical expressions, there are contrasting sentences indicated by the use of "padahal" (whereas) against the idea of rampant hoax reporting and conspiracy theories that have actually driven the public to ignore the dangers of this virus which has the impact of disrupting the handling of the Covid-19 pandemic. This contrasting proposition appeared in the editorial team of journalists who said that "Teori Konspirasi Selain hoaks, isu yang menyebut bahwa pandemi Covid-19 adalah konspirasi juga beredar di ruang publik dan dipercaya oleh segelintir masyarakat. Padahal, 26,52 juta orang di dunia telah terinfeksi virus corona". Blaming the discourse agents with the expression "segelintir masyarakat" (a handful of people) here is a form of indirectness mentioning the object of discourse that needs to be blamed. In terms of the sitanksis structure the lexical option is specified "segelintir masyarakat" obscuring the message of whoever is to blame, because previously Kompas.com in the news of Bill Gates, who masterminded the spread of Covid19 , seemed to support the linked propaganda argument.

Semantically, the second contrasting news from the previous one is supported by the use of vocabulary that supports the government to negate / reject the existence of propaganda on the Covid-19 issue, while several important words that appear include the word "berhatihati" (be extra careful) reflects a reminder. The word "berhati-hati" which shows this warning shows the ideological position of journalists who want to give the public impression that Kompas.com invites its audience to commit to obeying government regulations in handling Covid-19. This is as stated by the writer in the initial narrative of the news in the first paragraph "Bila tak hati-hati" (In case not be careful) (paragraph pertama), and in the statement he quoted to support the author's idea, namely the Task Force's statement Covid19, Wiku Adisasmito, "figur publik agar berhati-hati dalam menyampaikan informasi".

The superstructure relates to how events are organized in terms of introduction, substance, and conclusion on the one hand and what events are given more emphasis and 
stand out on the other. In this second story, the authors seem to argue a lot about ideas that support opposition to the alleged Covid-19 conspiracy and propaganda. In the news, it was stated that several public figures were involved in confusing the pandemic condition with accusations of conspiracy behind Covid-19, where one of them had been imprisoned by the authorities for unwarranted accusations to the Ikatan Dokter Indonesia (IDI) (Indonesian Doctors Association) as WHO lackeys. On several occasions, it was seen how journalists also quoted Septiaji's suggestion, the chairman of Mafindo, so that people were self-aware and able to filter out all forms of fake news about Covid-19 that intimidated medical personnel, said the journalist who quoted Septiaji that "perlu adanya literasi digital bagi masyarakat". The existence of fake news about Covid-19 circulating is damaging the efforts to handle this pandemic.

\section{Conclusion}

Analysis of the data in the discussion in this study proves that the pandemic known as Covid-19 has been politicized and used ideologically, including by Kompas.com journalists as news that needs to be raised with various consequences for its readers. In other words, two selected online news stories about hoaxes and conspiracy theories behind the Covid-19 pandemic published in different ranges by the same publisher give different impressions of the publishers. These two reports reflect the three structures of discourse, namely, the macro structure, the superstructure and the micro structure ideologically in their news. The two publications of the online daily newspaper Kompas.com emphasize different ideas, the first news shows the tendency of journalists who participated in promoting a strong allegation of conspiracy theories connecting global elite figures. In this initial news, there are no ideas that lead readers to further examine the alleged conspiracy theory news that connects Bill Gates and his company as figures who need to be suspected of this Covid-19 pandemic and seem to allow readers to conclude for themselves and agree to the truth of the allegations in the news. Ihe Schematic, micro and macro-structure structures in the second story reflect different semantic meanings and propositions. In this second report, the author argues a lot about ideas that support opposition to the alleged Covid-19 conspiracy and propaganda. In the news, it was stated that several public figures who were involved in confusing the conditions of the pandemic with accusations of conspiracy behind Covid-19 and the spread of hoaxes related to this pandemic ended up harming the person himself. Of course, in this second news, in the author's opinion he quoted many important figures from the Covid-19 Task Force and the chairman of Mafindo so that people think openly and participate in supporting the government and medical personnel in handling the Covid-19 case instead of worsening the situation by spreading fake news. And accuse medical personnel of taking advantage of the economy from this outbreak. 


\section{References}

Adida, C.L., K.Y. Dionne, and M.R. Platas. (2017). Ebola, elections, and immigration: how politicizing an epidemic can shape public attitudes. Politics, Groups, and Identities. https ://doi. org/10.1080/21565 503.2018.1484376.

Aini, N., and P. Widodo. (2018). Critical discourse analysis of the bombing attack news: an analysis of Teun A. van Dijk's model. In Advances in social science, education and humanities research, 165, 2nd international conference of communication science research (ICCSR 2018).

Ahmad Naufal Dzulfaroh (11 Juni 2020), "Mengapa Bill Gates Sering Jadi Sasaran Tudingan Teori Konspirasi Virus Corona?", https://www.kompas.com/tren/read/2020/06/11/110600165/mengapa-bill-gatessering-jadi-sasaran-tudingan-teori-konspirasi-virus?page=all\#page 2 .

Bukhari, N.H.S., and W. Xiaoyang. (2013). Critical discourse analysis and educational research. IOSR Journal of Research \& Method in Education 3, (1): 9-17.

Cotter, C. (2020). From the 'Spanish Flu' to COVID-19: lessons from the 1918 pandemic and First World War [Blog post]. https ://blogs .icrc.org/law-and-polic y/2020/04/23/spani sh-flu-covid -19- 1918-pande mic-first -world -war/

Drid, T. (2019). The study of news: a discourse analysis perspective. Journal El-Bahith in Human and Social Sciences, 10, (35): 701-708.

Devina Halim A (05 September 2020), Kompas.com dengan judul "6 Bulan Pandemi Covid19: Hoaks dan Teori Konspirasi yang Memperparah Penanganan...": https://nasional.kompas.com/read/2020/09/05/09090921/6-bulan-pandemi-covid-19hoaks-dan-teori-konspirasi-yang-memperparah?page=all\#page2 .

Hofstetter, C.R., and T.F. Buss. (1978). Bias in television news coverage of political events: a methodological analysis. Journal of Broadcasting, 22, (4): 517-530. https ://doi.org/10.1080/08838157809363907.

Huang, J. 2020. Chinese diplomat accuses US of spreading coronavirus [blog post]. https ://www. voane ws.com/scien ce-healt h/coron aviru s-outbr eak/chine se-diplo mataccus es-us-sprea ding-coron aviru s. Accessed 20 May 2020.

Marcus, J. 2020. Coronavirus: US-China battle behind the scenes [blog post]. https ://www.bbc. com/news/world -52008 453

Mullainathan, S., and A. Shleifer. (2002). Media Bias. Harvard Institute Research Working Paper No. 1981; MIT Department of Economics Working Paper No. 02-33. Available at SSRN: https ://ssrn. com/abstr act=33580 0. http://dx.doi.org/10.2139/ssrn.33580 0.

Thomas, L., W. Shan, S. Ishtla, S.P. Jean, T. Joanna, and J. Jason. (2004). Language, society, and power: an introduction. London: Routledge.

Kolsto, P. (2009). Media discourse and the Yugoslav conflicts: representations of self and other. Farnham: Ashgate

Little, B. (2020). Trump's 'Chinese' virus is part of a long history of blaming other countries for disease [blog post]. https ://time.com/58073 76/virus -name-forei gn-history/. Accessed 20 May 2020.

Page, C. (2020). Page: politicizing coronavirus hazardous to our national health [blog post]. https ://www.teleg raphh erald .com/ap/comme ntary /artic le_58ffb b41-0b5d-5ac2bfc1-bc590 ad5a6 99.html. Accessed 20 May 2020.

Pratiwi, A., and R. Refnaldi. (2018). Macrostructure and superstructure patterns of Jokowi's speeches. E-Journal of English Language \& Literature, 7, (4): 547-556.

Priadi, R., et al. (2018). ISIS Terror on detik.com Online Media in Indonesia. Budapest International Research and Critics Institute-Journal (BIRCI-Journal). P. 451-464. 
Qiu, L. 2017. Fingerprints of Russian disinformation: from AIDS to fake news [blog post]. https :// www.nytim es.com/2017/12/12/us/polit ics/russi an-disin forma tion-aidsfake-news.html

Rafida, T., and Jamilah. (2020). Implementation of Thematic Learning in Increasing Cognitive Development and Children Language in Raudhatul Atfhal Rahmat Islamiyah Medan. Budapest International Research and Critics Institute-Journal (BIRCI-Journal). P. 1023-1030.

Scott, C. 2014. The Ebola outbreak was political-just like every disease outbreak [blog post]. https ://www.theve rge.com/2014/12/30/74669 89/the-ebola -outbr eak-was-polit icaljust-like-every -disea se-outbr eak.

Van Dijk, T.A. (1988). News analysis: case studies of international and national news in the press. Hillsdale, NJ: Erlbaum.

Van Dijk, T.A. (1991). Racism and the press. London: Routledge.

Van Dijk, T.A. (1985). Structures of news in the press. In Discourse and communication, ed. T.A. Van Dijk. Berlin: De Gruyter.

Yarlott, W. V. H., C. Cornelio, T. Gao, and M. A. Finlayson. (2018). Identifying the discourse function of news article paragraphs. In: Proceedings of the workshop on events and stories in the news, 25-33 Santa Fe, New Mexico, USA.

Zhang, X., Y. Pan, and M. Zhang. (2014). Superstructure analysis in news stories: a contrastive study of superstructure in VOA, BBC, and NPR news. Asian Social Science 10, (22): 199-209. 